\title{
PENERAPAN MODEL PEMBELAJARAN MASTERY LEARNING UNTUK MENINGKATKAN KEMAMPUAN MERUMUSKAN HIPOTESIS FISIKA SISWA KELAS XI SMA NEGERI 3 SIBOLGA
}

\author{
Ferawati Artauli Hasibuan ${ }^{1)}$, Henry Dinus Hutabarat ${ }^{1)}$. \\ ${ }^{1)}$ Pendidikan Fisika, Fakultas Keguruan dan Ilmu Pendidikan, Universitas Graha Nusantara Padangsidimpuan \\ e-mail: ferawati.fa@gmail.com.
}

\begin{abstract}
Abstrak
Penelitian ini bertujuan untuk mengetahui besar peningkatan kemampuan merumuskan hipotesis fisika siswa kelas XI SMA Negeri 3 Sibolga melalui model pembelajaran Mastery Learning pada materi materi fluida statis. Jenis penelitian ini merupakan Penelitian Tindakan Kelas (PTK) yang terdiri dari 2 Siklus. Subjek penelitian adalah kelas XI-2 yang berjumlah 30 orang. Perangkat pembelajaran yang digunakan dalam penelitian ini adalah Rencana Pelaksanaan Pembelajaran (RPP), Buku Panduan Guru (BPG), Lembar Kerja Siswa (LKS), Instrumen Tes, dan aktivitas siswa. Adapun tes yang digunakan adalah tes bentuk essay yang sudah diujicobakan dengan reliabilitas tes siklus I sebesar 0,74 dengan tingkat reliabilitas tinggi dan tes siklus II sebesar 0,89 dengan tingkat reliabilitas tinggi. Dan kedua tes tesebut masing - masing memiliki 5 soal yang valid. Hasil penelitian menunjukkan bahwa hasil tes kemampuan merumuskan hipotesis fisika siswa dengan menerapkan model pembelajaran Mastery Learning pada siklus I diperoleh persentase minimal cukup baik sebesar 66,67 \% Dan pada siklus II meningkat menjadi 83,32\% dengan indikator pencapaian telah tercapai $\geq 80 \%$. Kemudian diperoleh kadar aktivitas siswa pada siklus I sebesar 69,63\% "Cukup" dan meningkat pada siklus II menjadi 88,63\% "Baik", indikator pencapain aktivitas pada siklus II juga tercapai yakni $\geq 80 \%$.
\end{abstract}

Kata Kunci: Model Pembelajaran, Belajar Tuntas, Rumusan Hipotesis Fisika, Fluida Statis

\begin{abstract}
This study discusses the improvement of the ability to form physics hypotheses of class XI students of SMA 3 Sibolga through the Mastery Learning model in a statistical fluid material. This type of research is a Classroom Action Research (CAR) consisting of 2 cycles. The research subject was class XI IPA 2 which tested 30 people. Learning Tools used in this study are Learning Implementation Plans (RPP), Teacher's Guidebook (BPKS), Student Worksheets (LKS), Test Instruments, Observation Sheets, and activities. While the test used is an essay form test that has been tested with the reliability of the first cycle test of 0.74 with a high level of reliability and the second cycle test of 0.89 with a high level of reliability. And both tests each have five valid questions. The results showed that the test results formulated the students' hypotheses by applying the Mastery Learning model in the first cycle obtained a fairly good percentage of $66.67 \%$ and in the second cycle increased to $83.32 \%$ with the indicators succeeding in getting $80 \%$. Then the activity rate of students in Cycle I is $69.63 \%$ "enough" and increased in cycle II to $88.63 \%$ "good" the indicator of the activity increase in cycle II is also reached $80 \%$.
\end{abstract}

Keywords: Learning Model, Mastery Learning, The Ability to Formulae Hypotheses Physic, Static Fluid

\section{PENDAHULUAN}

Pendidikan merupakan salah satu aspek dalam kehidupan yang memegang peranan penting. Suatu negara dapat mencapai sebuah kemajuan jika pendidikan dalam negara itu baik kualitasnya. Tinggi rendahnya kualitas pendidikan dalam suatu negara dipengaruhi banyak faktor misalnya dari siswa, pengajar, sarana prasarana, dan juga karena faktor lingkungan. Salah satu upaya meningkatkan kualitas pendidikan adalah meningkatkan pembelajaran disekolah. Salah satunya adalah pembelajaran fisika. 
Di dalam setiap proses pembelajaran, ada tiga aspek yang perlu diperhatikan, yaitu aspek kognitif, aspek afektif, dan aspek psikomotor. Ketiga aspek itu berturut-turut menyangkut ilmu pengetahuan, perasaan, dan keterampilan. Ketiga aspek tersebut harus berimbang agar tujun pengajaran dapat dicapai.

Salah satu diantara masalah besar dalam bidang pendidikan di Indonesia yang banyak diperbincangkan adalah rendahnya mutu pendidikan yang tercermin dari rendahnya rata-rata hasil belajar. Masalah lain dalam pendidikan di Indonesia yang juga banyak diperbincangkan adalah bahwa pendekatan dalam pembelajaran masih terlalu didominasi peran guru (teacher center). Guru banyak menempatkan siswa sebagai obyek dan bukan sebagai subyek didik. Pendidikan kita kurang memberikan kesempatan pada siswa dalam berbagai mata pelajaran untuk mengembangkan kemampuan berpikir holistik (menyeluruh), kreatif, objektif, dan logis. Belum memanfaatkan metode mengajar sebagai salah satu paradigma menarik dalam pembelajaran, serta kurang memperhatikan ketuntasan belajar secara individual.

Belajar dan mengajar merupakan dua konsep yang tidak bisa dipisahkan satu sama lain. Belajar menunjukkan kepada apa yang harus dilakukan seseorang sebagai penerima pelajaran (siswa), sedangkan mengajar menunjukkan kepada apa yang harus dilakukan oleh seorang guru yang menjadi pengajar. Jadi belajar mengajar merupakan proses interaksi antara guru dan siswa pada saat proses pengajaran. Proses pengajaran akan berhasil selain ditentukan oleh kemampuan guru dalam menentukan metode dan alat yang digunakan dalam pengajaran, juga ditentukan oleh minat belajar siswa.

Rendahnya hasil belajar siswa dikarenakan guru dalam menerangkan materi fisika kurang jelas dan kurang menarik perhatian siswa dan pada umumnya guru terlalu cepat dalam menerangkan materi pelajaran sehingga siswa dalam memahami dan menguasai materi masih kurang dan nilai yang diperoleh siswa cenderung rendah. Di sisi lain, pengajar cenderung mengajarkan dan memberi contoh yang tidak sesuai dengan lingkungan tempat tinggal mereka sehingga tidak menyaksikan secara langsung contoh yang diberikan. Masalahmasalah yang sering dijumpai diantaranya:

1. Siswa tidak mampu menguasai hubungan antar konsep.

2. Siswa kurang memperhatikan materi yang diberikan guru.

3. Siswa kurang dalam mengerjakan latihan-latihan soal.

4. Siswa malu bertanya tentang materi yang belum dimengerti.

Dengan tercapainya tujuan dan kualitas pembelajaran, maka dikatakan bahwa guru telah berhasil dalam mengajar. Keberhasilan kegiatan belajar mengajar tentu saja diketahui setelah diadakan evalusi dengan berbagai faktor yang sesuai dengan rumusan beberapa tujuan pembelajaran. Sejauh mana tingkat keberhasilan belajar mengajar, dapat dilihat dari daya serap anak didik dan persentase keberhasilan anak didik dalam mencapai tujuan pembelajaran khusus. Jika hanya tujuh puluh lima persen atau lebih dari jumlah anak didik yang mengikuti proses belajar mengajar mencapai taraf keberhasilan kurang (di bawah taraf minimal), maka proses belajar mengajar berikutnya hendaknya ditinjau kembali.

Setiap akan mengajar, guru perlu membuat persiapan mengajar dalam rangka melaksanakan sebagian dari rencana bulanan dan rencana tahunan. Dalam persiapan itu sudah terkandung tentang, tujuan mengajar, pokok yang akan diajarkan, metode mengajar, bahan pelajaran, alat peraga dan teknik evaluasi yang digunakan. Karena itu setiap guru harus memahami benar tentang tujuan mengajar, secara khusus memilih dan menentukan metode mengajar sesuai 
dengan tujuan yang hendak dicapai, cara memilih, menentukan dan menggunakan alat peraga, cara membuat tes dan menggunakannya, dan pengetahuan tentang alat-alat evaluasi.

$\begin{array}{ccc}\text { Salah satu cara untuk } \\ \text { meningkatkan } & \text { kemampuan dalam }\end{array}$
merumuskan hipotesis dalam pembelajaran fisika adalah melalui pendekatan belajar tuntas (mastery learning). Untuk dapat melakanakan pembelajaran fisika dengan pendekatan belajar tuntas maka diperlukan adanya kerja sama antara guru fisika dan peneliti yaitu melalui penelitian tindakan kelas (PTK). Proses PTK ini memberikan kesempatan kepada peneliti dan guru fisika untuk mengidentifikasi masalah-masalah pembelajaran di sekolah sehingga dapat dikaji, ditingkatkan dan dituntaskan. Dengan upaya ini diharapkan siswa memiliki pengetahuan ilmiah dalam merumuskan hipotesis dari masalahmasalah fisika dan pada akhirnya akan meningkatkan hasil belajar fisika.

Fisika adalah ilmu pengetahuan yang mempelajari mengenai komponen dasar dari jagad raya dan interaksiinteraksi yang terdapat di dalamnya. Fisika merupakan salah satu cabang dari ilmu pengetahuan alam (sains). Hakikat sains menurut Collete dan Chiappetta (1994) dalam (Zuhdan, 2004), meliputi: 1) pengumpulan pengetahuan (body of knowledge); 2) cara atau jalan berfikir ( $a$ way of thinking); 3) cara untuk penyelidikan (a way of investigating). Menurut Mundilarto (2002), Fisika merupakan ilmu yang berusaha memahami aturan-aturan alam yang begitu indah dan dengan rapi dapat dideskripsikan secara matematis.

Melalui pembelajaran Fisika diharapkan peserta didik dapat mengembangkan pemahaman serta kebiasaan berpikir secara kritis dalam memenuhi kebutuhan hidup ataupun untuk mengatasi berbagai permasalahan hidup yang dihadapi. Pembelajaran Fisika harus dapat mendorong peserta didik untuk menumbuhkan rasa ingin tahu, keterbukaan, dan kebiasaan berfikir rasional, sehingga peserta didik tidak hanya menganggap fisika sebagai materi pembelajaran namun lebih kepada bagaimana mereka memahami dunia.

Menurut Mundilarto (2002), proses sains diturunkan dari langkah-langkah yang dikerjakan saintis ketika melakukan penelitian ilmiah. Langkah-langkah tersebut disebut sebagai keterampilan proses sains yang mencakup observasi, mengukur, inferensi, memanipulasi variabel, merumuskan hipotesis, menyusun grafik dan tabel data, mendefinisikan secara operasional, dan melaksanakan eksperimen.

Model pembelajaran yang digunakan dalam penelitian ini adalah model mastery learning dengan tujuan meningkatkan kemampuan siswa merumuskan hipotesis fisika. Mastery Learning atau belajar tuntas adalah salah satu filsafat yang mengatakan bahwa dengan sistem pengajaran yang tepat semua siswa dapat belajar dengan hasil yang baik hampir seluruh materi pelajaran yang diajarkan disekolah.

Menurut Suryosubroto (2009) "Mastery learning merupakan suatu pendekatan pembelajaran yang menganut azas ketuntasan belajar”. Belajar tuntas (Mastery Learning) adalah pendekatan pembelajaran berdasar pandangan filosofis bahwa seluruh peserta didik dapat belajar jika mereka mendapat dukungan kondisi yang tepat. Nasution (2009) menjelaskan bahwa "mastery learning dalam proses mengajar-belajar secara ideal adalah agar bahan yang dipelajari dapat dikuasai sepenuhnya oleh siswa”. Dalam usaha mencapai penguasaan penuh perlu diselidiki prasyarat bagi pengesuaian itu. Salah satu Prasyaratnya adalah merumuskan secara khusus bahan yang harus dikuasi dan tujuan itu harus dituangkan dalam alat evaluasi yang bersifat sumatif agar dapat diketahui tingkat keberhasilan siswa.

Pendekatan pembelajaran tuntas (mastery learning) adalah salah satu usaha 
dalam pendidikan yang bertujuan untuk memotivasi peserta didik mencapai penguasaan (mastery level) terhadap kompetensi tertentu. Pembelajaran tuntas merupakan salah satu prinsip utama dalam mendukung pelaksanaan kurikulum di sekolah. Oleh karena itu pembelajaran tuntas merupakan suatu alternatif strategi pembelajaran yang harus dipahami dan dilaksanakan dengan sebaik- baiknya oleh seluruh lembaga pendidikan

Model belajar tuntas ini terdiri atas lima tahap, yaitu orientasi (orientation), penyajian (presentation), latihan terstruktur (structured practice), latihan terbimbing (guided practice) dan latihan mandiri (independent practice). Tujuan proses belajar mengajar secara ideal adalah agar bahan yang dipelajari dikuasai sepenuhnya oleh peserta didik. Ini disebut mastery learning atau belajar tuntas, artinya penguasaan penuh (Nasution, 2013).

Pembelajaran fisika membantu peserta didik untuk mengembangkan diri menjadi individu yang memiliki sikap ilmiah, mampu memproses fenomena dan pengetahuan yang diperoleh serta mampu memahami bagaimana fenomenafenomena yang ada di sekitarnya bekerja. Salah satu pendekatan yang sesuai dalam pembelajaran fisika yaitu dengan pendekatan keterampilan proses merumuskan hipotesis.

Hipotesis adalah suatu pernyataan atau pendapat yang pada waktu diungkapkan belum diketahui kebenarannya tetapi memungkinkan untuk diuji kebenarannya dalam kenyataan empiris (Gulo, 2000). Hipotesis dapat dirumuskan dengan penalaran induktif berdasarkan data hasil pengamatan dan penalaran deduktuf berdasarkan teori. Merumuskan hipotesis merupakan hal yang penting dalam meningkatkan kreativitas ilmiah.

Menurut Malo \& Trisnoningtias (1994), perumusan hipotesis paling kurang ada tiga macam, yakni yang bersifat deskriptif yaitu menggambarkan karakteristik suatu satuan awal yang menjadi fokus perhatian penelitian, korelasional yaitu menggambarkan hubungan antara dua atau lebih variabel tetapi tidak menunjukkan variabel mana yang menjadi sebab dan variabel mana yang menjadi akibat dalam hubungan tersebut, dan kausal yaitu menunjukkan variabel mana yang menjadi sebab dan variabel mana yang menjadi akibat. Dalam merumuskan sebuah hipotesis memiliki beberapa ciri-ciri yaitu: menyatakan hubungan antar variabel, sesuai dangan fakta, berhubungan sesuai dengan ilmu pengetahuan, dapat diuji, sederhana dan dibatasi, serta dapat menerangkan fakta.

\section{METODE}

Penelitian ini dilakukan di kelas XI SMA Negeri 3 Sibolga. Subjek dalam penelitian tindakan kelas ini adalah siswa kelas XI IPA-2 Negeri 2 Sibolga sebanyak 30 siswa Jenis penelitian ini adalah penelitian tindakan kelas (classroom action research) melalui model pembelajaran mastery learning dengan tujuan memperoleh data kauntiatif atau tingkat kesuliatan siswa dalam merumuskan hipotesis fisika melalui penyelesaian soal materi fluida statis.

Observasi dibagi dalam dua siklus, yaitu siklus I, dan siklus II, dimana masing putaran dikenai perlakuan yang sama (alur kegiatan yang sama) dan membahas satu sub pokok bahasan yang diakhiri dengan tes formatif di akhir masing putaran. Dibuat dalam dua putaran dimaksudkan untuk memperbaiki sistem pengajaran yang telah dilaksanakan.

Desain penelitian ini adalah penelitian tindakan kelas (Classroom Action Research). Menurut Kemmis dan Mc. Teggart dalam (Arikunto, 2006), Penelitian tindakan kelas dilaksanakan dalam siklus-siklus dengan setiap siklus tindakan meliputi perencanaan tindakan (Planning), pelaksanaan tindakan (Acting), pengamatan (Observation), refleksi 
PeTeKa (Jurnal Penelitian Tindakan Kelas dan Pengembangan Pembelajaran)

Vol 2 No 1 Tahun 2019 Hal 22 - 29

(Reflecting).

Sumber data dalam penelitian ini terdiri dari beberapa sumber yakni siswa, guru, teman sejawat, dan kolaborator. Instrumen yang digunakan dalam penelitian ini adalah tes. Tes yang digunakan berupa essay yang disusun berdasarkan isi materi sistem persamaan linear dua variabel yang diujikan di setiap akhir siklus. Dalam hal ini soal yang diambil dari kumpulan soal-soal fisika buku panduan fisika serta semua buku yang bersesuaian dengan materi. Kemudian dianalisis validitas tes. Reliabilitas tes, daya pembeda, dan tingkat kesukaran tes.

Suatu tes dikatakan memiliki validitas jika hasilnya sesuai dengan kriteria, dalam arti memiliki kesejajaran antara hasil test tersebut dengan kriteria. Dari hasil perhitungan koefesien korelasi, item soal dapat dinyatakan valid jika $\mathrm{r}_{\text {hitung }}>\mathrm{r}$ tabel untuk taraf signifikansi $\alpha=$ 0,05. Reliabilitas test berhubungan dengan masalah kepercayaan. Suatu soal dapat dinyatakan mempunyai taraf kepercayaan yang tinggi jika soal tersebut dapat memberi hasil yang tetap. Daya beda soal adalah kemampuan sesuatu soal untuk membedakan antara siswa yang pandai (berkemampuan tinggi) dengan siswa yang kurang pandai (berkemampuan rendah). Angka yang menunjukkan besar daya pembeda soal disebut indeks diskriminasi, disingkat dengan D. Taraf kesukaran soal ditunjukan oleh besar indeks kesukaran soal (difficulty index), yaitu bilangan menunjukkan sukar mudahnya suatu soal.

\section{HASIL DAN PEMBAHASAN}

Setelah dilaksanakan penelitian, data yang diperoleh dari lapangan diolah atau dianalisis untuk dapat diberi kesimpulan tentang usaha dan energi pada kelas XI SMA Negeri 3 Padangsidimpuan. Data yang dikumpulkan dalam penelitian ini meliputi dua data dari variabel penelitian yang terdiri dari satu variabel terikat dan satu variabel bebas.

\section{Deskripsi Hasil Penelitian Tindakan Kelas Siklus I}

Siklus 1 merupakan pembelajaran dengan pokok bahasan fluida statis. Diakhir pembelajaran siklus 1 berlangsung, pada pertemuan ke 5 dilaksanakan tes belajar siswa, maka hasil yang didapat dari tes tersebut dapat dilihat pada tabel 1 berikut ini.

Tabel 1. Deskripsi Nilai Hasil Tes Kemampuan Merumuskan Hipotesis Fisika Siklus I

\begin{tabular}{|c|c|c|c|c|}
\hline No & Nilai & $\begin{array}{c}\text { Jumlah } \\
\text { Siswa } \\
\text { (Orang) }\end{array}$ & $\begin{array}{c}\text { Persentase } \\
(\%)\end{array}$ & Kategori \\
\hline 1 & $90-100$ & 5 & 16,67 & $\begin{array}{c}\text { Sangat } \\
\text { Baik }\end{array}$ \\
\hline 2 & $80-89$ & 6 & 20 & Baik \\
\hline 3 & $65-79$ & 9 & 30 & $\begin{array}{c}\text { Cukup } \\
\text { baik }\end{array}$ \\
\hline 4 & $55-64$ & 4 & 13,33 & Kurang \\
\hline 5 & $0-54$ & 6 & 20 & $\begin{array}{c}\text { Sangat } \\
\text { Kurang }\end{array}$ \\
\hline
\end{tabular}

Dari 30 siswa yang mengikuti tes 16,67\% dengan kriteria "sangat baik”, 620 \% dengan kriteria "baik”, 30\% dengan kriteria "cukup", 13,33\% dengan kriteria "kurang”, dan 20\% dengan kriteria 'sangat kurang”. Secara klasikal kemampuan siswa dalam merumuskan hipotesis fisika yang memperoleh minimal "cukup baik" 20 siswa atau 66,67 \% dari 30 siswa yang mengikuti teks. hal ini menunjukkan tingkat penalaran siswa masih "belum memenuhi kriteria”. Berdasarkan hasil tersebut, bahwa kriteria penilaian yang telah di tetapkan masih belum terpenuhi yaitu $80 \%$ dari seluruh siswa yang mengikuti tes. Berdasarkan hasil ini maka peneliti akan mengadakan perbaikan pada siklus berikutnya untuk meningkatkan kemampuan penalaran siswa.

Ditinjau dari segi kemampuan siswa dalam merumuskan hipotesis fisika, masih ditemukan siswa yang tidak mampu menyelesaikan soal terkait dengan 
penalaran siswa. Hal ini disimpulkan karena jawaban siswa masih banyak yang salah dan juga masih ditemukan jawaban yang kosong.

Adapun hasil pengamatan observer terhadap aktivitas siswa dalam pembelajaran dilaksanakan setiap kali pertemuan. Dimana pada siklus I diadakan 4 kali pertemuan. Secara keseluruhan aktivitas siswa pada siklus I kadar aktivitas siswa belum sesuai dengan kadar yang diharapkan dalam penelitian ini yaitu $\geq$ $80 \%$, hal ini dapat dilihat pada gambar 1 .

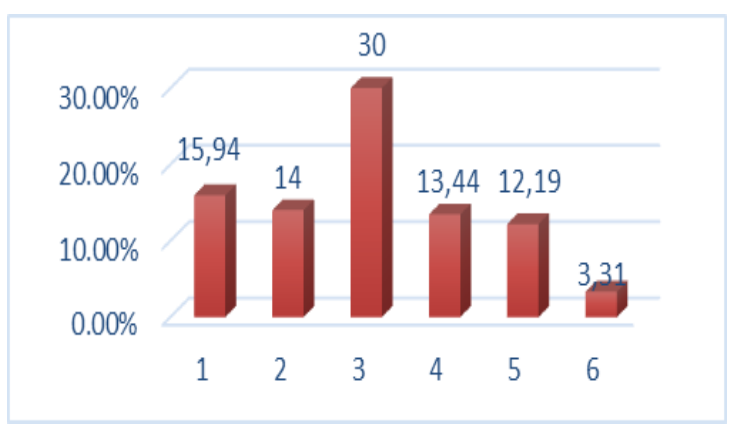

Gambar 1. Diagram aktivitas siswa siklus I

\section{Deskripsi Hasil Peneltian Tindakan Kelas Siklus II}

Perencanaan siklus II merupakan lanjut refleksi pada siklus I, dengan revisi/perbaikan instrumen tes dan perangkat pembelajaran berupa RPP, lembar aktivitas siswa dan buku pedoman guru. Adapaun perubahan perbaikan intrumen tes dan perangkat pembelajaran sebangai berikut:

1. Siklus I, Siswa kurang memahami soal sehingga hasil dari jawaban siswa kurang memuaskan sehingga pada siklus II instrumen tes dalam merumuskan hipotesis fisika direvisi soal nomor 4 dan 5.

2. Peranan guru hanya sebagai fasilitator, manager, dan konsultan pada kegiatan pembelajaran, sehingga intervensi guru jika diperlukan saja.

3. Guru selalu memperhatikan alokasi waktu yang ada pada perencanaan, sehingga sesuai dengan waktu tindakan.
4. Siswa diberikan kesempatan seluasluasnya mendiskusikan masalahnya.

Siklus II sama seperti siklus I, siklus yang terdiri dari 4 tahapan. Kegiatan ini dilaksanakan karena melihat hasil refleksi dari siklus I. Hasil yang diperoleh belum sesuai dengan harapan dikarenakan guru belum terbiasa dengan penerapan strategi pembelajaran mastery learning. Sama dengan siklus I diakhir pembelajaran siklus II berlangsung, pada pertemuan ke 5 dilaksanakan tes penalaran siswa, maka hasil yang didapat dari tes tersebut dapat dilihat pada tabel 2 .

Tabel 2. Deskripsi nilai hasil tes kemampuan merumuskan hipotesis fisika siklus II

\begin{tabular}{|c|c|c|c|c|}
\hline No & Nilai & $\begin{array}{c}\text { Jumlah } \\
\text { Siswa } \\
\text { (Orang) }\end{array}$ & $\begin{array}{c}\text { Persentase } \\
(\%)\end{array}$ & Kategori \\
\hline 1 & $90-100$ & 7 & 23,33 & $\begin{array}{c}\text { Sangat } \\
\text { Baik }\end{array}$ \\
\hline 2 & $80-89$ & 11 & 36,66 & Baik \\
\hline 3 & $65-79$ & 7 & 23,33 & Cukup \\
\hline 4 & $55-64$ & 3 & 10,00 & Kurang \\
\hline 5 & $0-54$ & 2 & 6,67 & $\begin{array}{c}\text { Sangat } \\
\text { Kurang }\end{array}$ \\
\hline
\end{tabular}

Dari 30 siswa yang mengikuti tes diperoleh 23,33\% dengan kriteria " sangat baik”, 36,66\% dengan kriteria "baik”, 20,00\% dengan kriteria “ cukup”, 10,00\% dengan kriteria “ kurang” dan 6,67\% dengan kriteria “ sangat kurang”. Secara klasikal diperoleh kriteria penilaian 83,32\%. Hal ini menunjukkan tingkat kemampuan siswa fisika "baik". Karena sudah memenuhi kriteria penilaian yaitu $\geq$ 80\%. Dari hasil tersebut penelitian ini diberhentikan karena sudah memenuhi kriteria yang diharapkan dan diharapkan dan diharapkan mastery learning dapat diterapkan pada pembelajaran selanjutnya.

Berdasarkan hasil observasi aktivitas siswa pada siklus II dalam 4 kali pertemuan. Secara keseluruhan pencapaian 
PeTeKa (Jurnal Penelitian Tindakan Kelas dan Pengembangan Pembelajaran)

Vol 2 No 1 Tahun 2019 Hal 22 - 29

aktivitas siswa pada siklus II dapat dilihat pada gambar 2 .

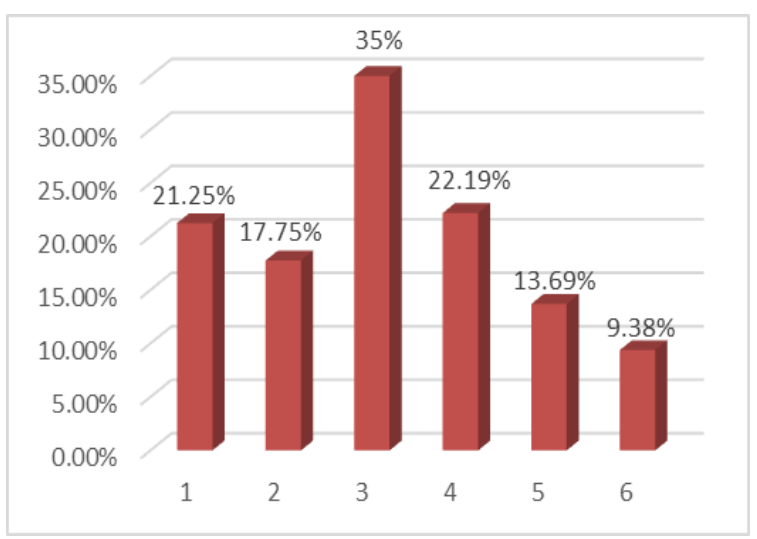

Gambar 2. Diagram aktivitas siswa siklus II

Dari gambar 3, aktivitas siswa pada siklus II mencapai 84,875\%, hal ini menunjukkan hasil observasi aktivitas siswa sudah sesuai dengan hasil yang di harapkan dalam penelitian ini yaitu $\geq$ 80\%. Peningkatan kemampuan siswa dalam merumuskan hipotesis fisika dari siklus I ke siklus II dapat dicermati grafik pada gambar 3.

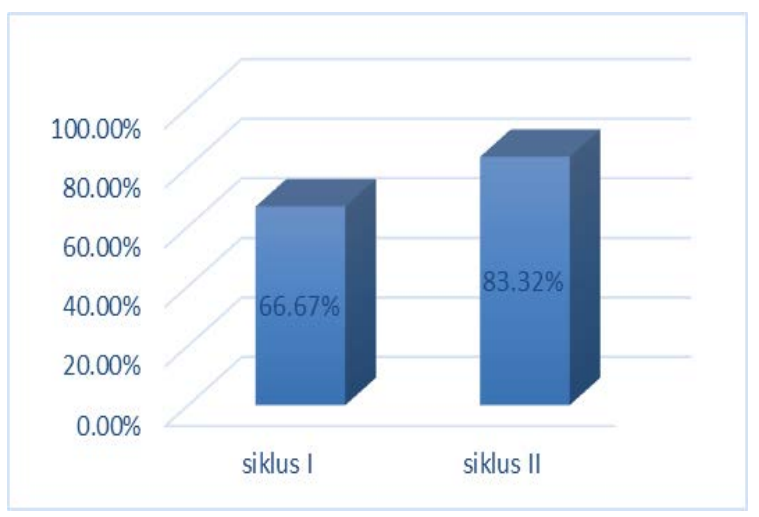

Gambar 3. Peningkatan kemampuan siswa merumuskan hipotesis siswa dari siklus I ke siklus II

Gambar grafik 3 menunjukkan bahwa dengan model pembelajaran mastery learning dapat meningkatkan kemampuan siswa dalam merumuskan hipotesis fisika di kelas X-2 SMA N 3 Sibolga sebesar $\leq 80 \%$.

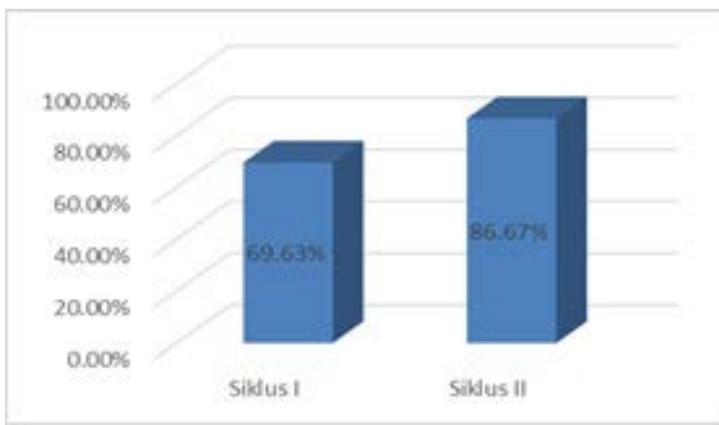

Gambar 4. Peningkatan aktivitas siswa dari siklus I ke siklus II

Pada siklus I, aktivitas siswa tidak memenuhi kriteria yang ditentukan yaitu $50 \%$ dengan kategori "kurang". Pada siklus II aktivitas siswa meningkat menjadi 83,33\% dengan kategori "baik". Peningkatan aktivitas ini mengakibatkan terjadinya peningkatan prestasi pada siswa.

\section{SIMPULAN}

Berdasarkan hasil penelitian maka diperoleh kesimpulan bahwa:

1. Kemampuan siswa dalam merumuskan hipotesis fisika setelah di laksanakan penelitian meningkat pada siklus I $66,67 \%$ dan pada siklus II mencapai $86,67 \%$. Hasil yang didapat pada siklus II menunjukkan bahwa sudah dapat terpenuhi kategori yang diharapkan yaitu $\geq 80 \%$.

2. Aktivitas siswa di kelas XI IPA 2 meningkat dengan penggunaan model pembelajaran mastery learning. Hal ini dapaat dilihat dari hasil observasi aktivitas siswa siklus I 69,63\% dan siklus II 88,63\%, Hasil yang diperoleh telah terpenui yaitu $\geq 80 \%$.

\section{DAFTAR PUSTAKA}

Arikunto, S. (2006). Prosedur penelitian suatu pendekatan praktik. Jakarta : Rineka Cipta.

Collette, A.T. \& Chiappetta, E. L. (1994). Science Instruction in the middle and secondary schools (3rd edition.). New York: Merrill. 
Gulo, W. 2000. Metodologi penelitian. Jakarta : PT Grasindo Anggota IKAPI.

Malo, Manasse, \& Sri, T. (1994). Metode penelitian masyarakat. Jakarta: Pusat Antar Universitas Ilmu-ilmu Sosial U.I.

Mundilarto. (2002). Kapita selekta pendidikan fisika. Yogyakarta: FMIPA UNY.

Nasution, S. (2009). Metode research (penelitian ilmiah). Jakarta: Bumi Aksara.

Nasution, S. (2013). Berbagai pendekatan dalam proses belajar mengajar. Jakarta : Bumi Aksara.

Suryosubroto. (2009). Proses belajar mengajar di sekolah. Jakarta: Rineka Cipta.

Zuhdan K. Prasetyo. (2013). Konsep dasar pendidikan IPA. Yogyakarta: FMIPA UNY. 